\title{
Pengembangan Sediaan Serbuk Antidiabetes dari Kombinasi Ekstrak Kulit Buah Manggis (Garcinia mangostana L.) dan Ekstrak Daun Salam (Syzygium polyanthum (Wight) Walp.)
}

\author{
Rizki Yulianti*, Partomuan Simanjuntak, Anny Victor Purba
}

Faculty of Pharmacy, Universitas Pancasila, Indonesia

\begin{tabular}{l}
\hline \hline \multicolumn{1}{c}{ Article info } \\
History \\
Submission: 28-12-2019 \\
Review: 29-12-2019 \\
Accepted: 22-02-2020 \\
*Email: \\
rizkiyulianti.r@gmail.com
\end{tabular}

DOI: $10.33096 /$ jffi.v7i1.593

Keywords:

Mangosteen; Salam leaf; antidiabetic; blood glucose; powder dosage form

\begin{abstract}
Diabetes mellitus is a metabolic disease characterized by hyperglicemic. Mangosteen (Garcinia mangostana L.) and Salam (Syzygium polyanthum (Wight) Walp.) are plants which recognized as blood glucose controller. The study aims to determine the effectiveness of the combination of the two extract in decreasing blood sugar levels of diabetic rats. The rats divided into 6 groups: group I (normal control) without treatment, group II (negative control), group III (positive control), group IV (extract of mangosteen with dose of $400 \mathrm{mg}$ ), group V (extract of salam leaf with dose of $400 \mathrm{mg}$ ) and group VI (combination of mangosteen $200 \mathrm{mg}$ and salam leaf $200 \mathrm{mg}$ ). Data were analyzed by One-Way Anova, followed by PostHoc Bonferroni analysis. Then the combination of the extract was formulated in powder dosage form blended with PVP, Sucralose and Lactose. The evaluation included physical test are organoleptic, water content and flowability time. The results showed that the combination of the extracts of mangosteen and salam leaf comprising half doses of eact extract could lower blood glucose levels significantly $(P<0.05)$ with better efficacy than each single extract and the combination of extracts able to produce powder dosage form with the requirement (organoleptic, water content and flowability time).
\end{abstract}

\section{Pendahuluan}

Diabetes melitus adalah penyakit metabolik yang ditandai dengan hiperglikemia akibat sekresi insulin, kerja insulin atau keduanya, dimana pankreas tidak memproduksi cukup insulin atau tubuh tidak dapat menggunakan insulin secara efektif. Insulin adalah hormon yang mengatur keseimbangan kadar gula darah. Gejala hiperglikemia ditandai dengan poliuria, polidipsia, penurunan berat badan, kadang-kadang dengan polifagia dan penglihatan kabur. Penurunan pertumbuhan dan kerentanan terhadap infeksi tertentu mungkin juga menyertai hiperglikemia kronis (American Diabetes Association, 2014). Diabetes dengan komplikasi merupakan penyebab kematian tertinggi ketiga di Indonesia (Pusat Data dan Informasi Kemenkes RI, 2013)

Pada tahun 2017, 425 juta orang dewasa dengan diabetes melitus (DM), kenaikan 4 kali lipat dari jumlah 108 juta di tahun 1980an. Pada tahun 2045 diperkirakan jumlahnya akan menjadi 693 juta. Menurut data International Diabetes Ferederation (IDF) pada tahun 2017, Indonesia menempati peringkat ke-6 di dunia dengan jumlah estimasi orang dengan DM sebesar 10,3 juta, prevalensi penderita DM tertinggi bersama China, India, Amerika, Brazil dan Mexico (International Diabetes Federation, 2017). Pengobatan penyakit DM membutuhkan waktu yang cenderung lama dengan biaya pengobatan yang relatif tinggi serta efek samping obat sintetik yang ditimbulkan jika penggunaan dalam jangka panjang menjadi salah satu pertimbangan masyarakat beralih pada penggunaan obat tradisional. Menurut WHO (2013) penggunaan obat tradisional mengalami peningkatan pada berbagai negara (World Health Organization, 2013).

Kulit buah manggis telah diteliti memiliki efek farmakologi sebagai antidiabetes (Pasaribu dkk, 2012). Pada penelitian sebelumnya menunjukkan bahwa ekstrak kulit buah manggis memiliki efek antihiperglikemia terhadap tikus putih jantan, diketahui di dalam kulit buah manggis kaya akan antioksidan seperti xanthone dan antosianin (Manurung dkk, 2012).

Daun salam merupakan salah satu obat herbal yang banyak dikonsumsi masyarakat. Pada penelitian sebelumnya juga menunjukkan bahwa ekstrak etanol daun salam pada dosis 249,6 $\mathrm{mg} / \mathrm{kgBB}$ dan 499,2 mg/kgBB dapat menurunkan kadar glukosa darah mencit yang diinduksi aloksan sebanding dengan glibenklamid (Dewi dkk, 2013).

Berdasarkan informasi tersebut diatas, perlu dilakukan uji aktivitas tunggal dan kombinasi ekstrak kulit buah manggis dan ekstrak daun salam sebagai antidiabetes serta inovasi dalam bentuk 
sediaan serbuk agar dapat dimanfaatkan secara praktis tanpa menyeduh atau merebus terlebih dahulu dan juga dimaksudkan sebagai pengobatan komplemen dalam meningkatkan kualitas hidup pada penderita diabetes melitus.

\section{Metode Penelitian \\ II.1 Bahan}

Masing-masing Ekstrak kulit buah manggis dan ekstrak daun salam dengan dosis $200 \mathrm{mg} / \mathrm{kgBB}$ dan $400 \mathrm{mg} / \mathrm{kgBB}$, etanol p.a, kloroform, dragendrof, mayer, wagner, $\mathrm{FeCl}_{3} 10 \%, \mathrm{NaOH} 10 \%$, $\mathrm{HCl} 10 \%$, Laktosa monohydrat $\left(\right.$ Meggle $\left.^{\circledR}\right)$ pharmaceutical grade, PVP (JH Nanhang $\left.{ }^{\circledR}\right)$ pharmaceutical grade, Sukralosa $\left(K^{2} b^{\circledR} o^{\circledR}\right)$ pharmaceutical grade, Aloksan dosis $125 \mathrm{mg} / \mathrm{kg}$.

\section{II.2 Metode}

\section{Ekstraksi}

Masing-masing kulit buah manggis dan daun salam sebanyak $1 \mathrm{~kg}$ dibuat simplisia kering selanjutnya diserbukkan kemudian dimaserasi dengan pelarut etanol $70 \%$ dengan perbandingan serbuk sampel dan pelarut yaitu 1:5-1:10, selanjutnya disaring, filtrat yang terkumpul diuapkan pelarutnya sehingga diperoleh ekstrak kental.

\section{Uji aktivitas antidiabetes ekstrak}

Digunakan tikus putih strain Sprague Dawley jantan, berumur 2 bulan, bobot badan $\geq 200$ gram. Hewan coba dikelompokkan menjadi 6 kelompok (@4 ekor), kecuali kelompok kontrol normal diinduksi aloksan. Kelompok I: kontrol normal (diberikan aquades), II: kontrol negatif (diinduksi aloksan), III: kontrol positif (diberikan Glibenklamid), IV: kelompok perlakuan (diberikan ekstrak kulit buah manggis dosis $400 \mathrm{mg} / \mathrm{kgBB}$ ), V (diberikan ekstrak daun salam dosis $400 \mathrm{mg} / \mathrm{kgBB}$ ), VI: (diberikan kombinasi ekstrak Kulit Buah Manggis $200 \mathrm{mg} / \mathrm{kg}$ BB dan ekstrak Daun Salam $200 \mathrm{mg} / \mathrm{kg} \mathrm{BB}$ ). Perlakuan dilakukan selama 28 hari, dan ditimbang berat badan tikus serta diukur kadar glukosa pada awal, hari-0, ke-7, ke-14, ke-21, dan ke-28 dengan metode glukometer.

\section{Pembuatan sediaan serbuk}

Masing-masing ekstrak kental kulit buah manggis dan ekstrak daun salam dibuat ekstrak kering dengan vakum dry, diayak dengan ayakan mesh 30 dan ditimbang sesuai formula dengan variasi PVP sebagai pengikat. Massa disimpan dan dikeringkan pada oven suhu $40-50^{\circ} \mathrm{C}$ kemudian dikemas.

\section{Analisis data}

Data diperoleh dari pengamatan dan pemeriksaan pengujian aktivitas antidiabetes, data dari hasil pengukuran dinilai normalitas dan homogenitasnya dengan menggunakan uji ShapiroWilk dan uji Levene's test. Data menunjukkan normal dan terdistribusi secara homogen bila nilai $p>0,05$. Untuk menguji efektivitas semua kelompok bersama dilakukan One Way Anova, dan uji lanjut Post Hoc Multiple Comparisons dengan metode uji Bonferroni.

\section{Hasil Dan Pembahasan}

Determinasi, rendamen, DER-native, organoleptik

Hasil determinasi buah manggis dan daun

salam di Herbarium Bogorinensis nomor 2476/IPH.1.01/If.07/XI/2017 menunjukkan bahwa tanaman yang digunakan sebagai bahan penelitian adalah benar kulit buah manggis (Garcinia mangostana L.) dan daun salam (Syzygium polyanthum (Wight) Walp.). Diperoleh rendamen dari masing-masing ekstrak adalah sebesar 11,06\% dan $21,51 \%$ serta DER-native kulit buah manggis dan daun salam berturut-turut sebesar 9,041 dan 4,649. Berdasarkan hasil pengamatan organoleptik yang diperoleh ekstrak etanol kulit buah manggis berbentuk ekstrak kental (pasta), berwarna coklat, berbau khas ekstrak dan berasa pahit. Untuk ekstrak etanol daun salam berbentuk ekstrak kental (pasta), berwarna hijau kehitaman, berbau khas ekstrak dan berasa pahit kesat. Rasa pahit pada kedua ekstrak disebabkan adanya kandungan saponin dalam ekstrak kulit buah manggis dan ekstrak daun salam (Rohyani, 2015).

\section{Penapisan fitokimia}

Hasil penapisan fitokimia ekstrak kulit buah manggis dan daun salam menunjukkan bahwa ekstrak kulit buah manggis dan ekstrak daun salam mengandung senyawa flavonoid dan saponin. Senyawa Kuinon hanya terdapat pada ekstrak kulit buah manggis, sedangkan senyawa tanin dan steroid terdapat pada ekstrak daun salam.

\section{Aktivitas antidiabetes}

Penelitian ini dinyatakan lolos kode etik berdasarkan surat pernyataan ethical clearance dengan nomor protokol 005-2018 KEH TROP BRC. Sebelum diinduksi aloksan, semua kelompok tikus (I-VI) diukur kadar glukosa darah normal, untuk mengetahui perbedaan kadar glukosa normal dan post aloksan. Hasilnya semua keompok menunjukkan nilai $\leq 135 \mathrm{mg} / \mathrm{dL}$ dimana nilai tersebut memenuhi nilai persyaratan kadar glukosa darah normal. Dibuat model tikus DM dengan induksi aloksan secara intraperitoneal, dan dilakukan pengukuran kadar glukosa untuk memastikan terjadi peningkatan kadar glukosa darah (tikus kondisi DM), hasilnya menunjukkan semua tikus (kecuali tikus pada kelompok kontrol normal) mengalami peningkatan kadar glukosa darah yaitu diatas kadar normal $\geq 135 \mathrm{mg} / \mathrm{dL}$.

Tikus diberikan ekstrak tunggal dan kombinasi serta kontrol positif secara oral menggunakan spoit oral, satu kali dalam sehari (pada pagi hari). Pengukuran kadar glukosa darah awal dan akhir bertujuan untuk mengetahui apakah kelompok tikus hiperglikemia yang diberikan bahan uji ekstrak kulit buah manggis, ekstrak daun salam, 
dan kombinasi ekstrak mengalami penurunan kadar glukosa darah atau tidak, hasilnya dapat dilihat pada Gambar 1.

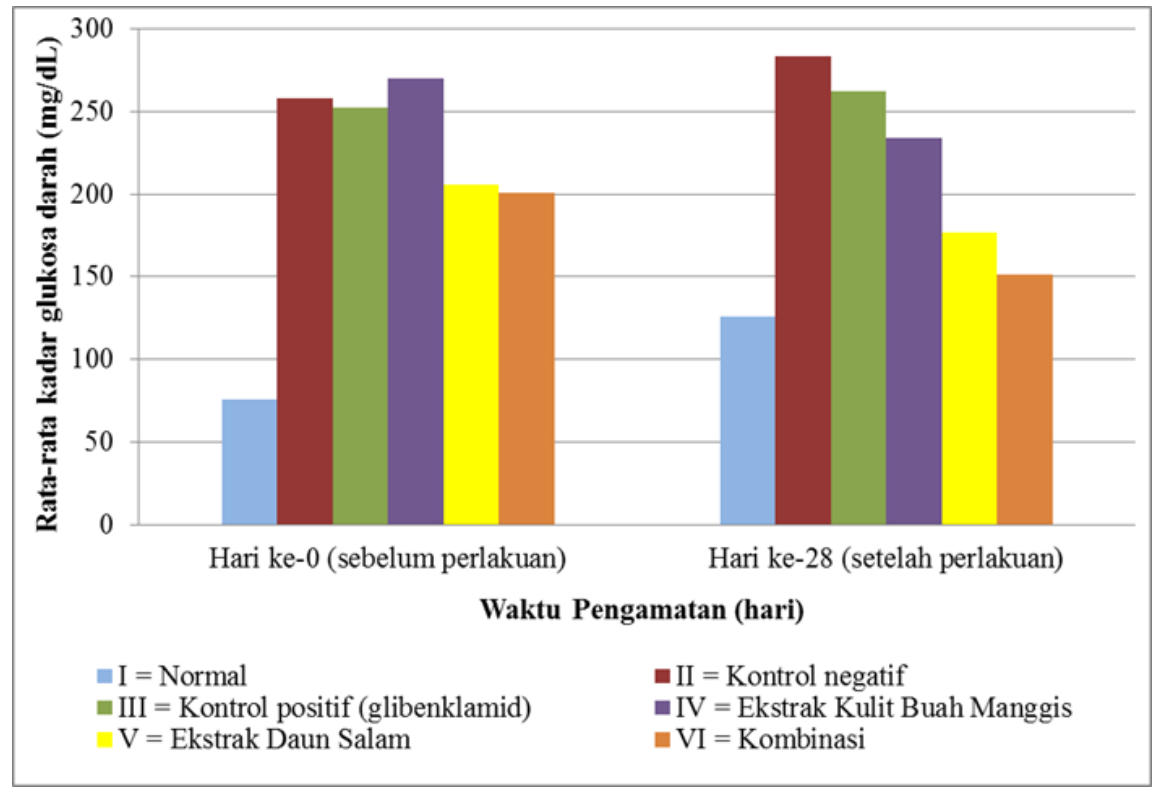

Gambar 1. Rata-rata kadar glukosa darah pada awal dan akhir perlakuan

Sebagaimana ditunjukkan pada Gambar 1 didapatkan pada kelompok III yang diberikan Glibenklamid dan semua kelompok ekstrak terjadi penurunan yang bermakna kadar glukosa darah pada tikus yang diinduksi aloksan setelah diberikan perlakuan selama 28 hari. Kelompok kontrol negatif juga mengalami penurunan, penurunan tersebut dapat disebabkan oleh respon tubuh masing-masing tikus putih yang tidak sama terhadap penyuntikkan aloksan dan kenaikan kembali kadar glukosa baik pada kelompok normal maupun perlakuan dikarenakan pengaruh stres hewan coba sebagai akibat penelitan (Nandhagopal et al, 2013).

Berdasarkan data rata-rata kadar glukosa darah dapat dilihat rata-rata penurunan kadar glukosa darah sebelum dan sesudah pada Tabel 1 . Berdasarkan Tabel 1, diketahui bahwa rata-rata kadar glukosa darah terendah pada kelompok VI yaitu kelompok tikus yang diberikan kombinasi ekstrak kulit buah manggis dan ekstrak daun salam, diikuti kelompok V, IV, dan III. Hal ini berarti dapat dikombinasikan antara kedua ekstrak tersebut.

Tabel 1. Rata-rata kadar glukosa darah sebelum dan sesudah perlakuan

\begin{tabular}{ccccc}
\hline No & Kelompok & $\begin{array}{c}\text { Sebelum perlakuan } \pm \\
\text { SD }(\mathbf{m g} / \mathbf{d L})\end{array}$ & $\begin{array}{c}\text { Sesudah perlakuan } \pm \\
\text { SD }(\mathbf{m g} / \mathbf{d L})\end{array}$ & $\begin{array}{c}\text { Rata-rata } \\
\pm \text { SD }(\mathbf{m g} / \mathbf{d L})\end{array}$ \\
\hline 1. & I & $75,75 \pm 11,17$ & $126,50 \pm 7,54$ & $101,13 \pm 9,36$ \\
2. & II & $257,75 \pm 45,44$ & $383,50 \pm 12,28$ & $320,63 \pm 28,86$ \\
3. & III & $252,50 \pm 40,36$ & $261,75 \pm 31,97$ & $257,13 \pm 36,17$ \\
4. & IV & $270,50 \pm 94,84$ & $234,25 \pm 90,55$ & $252,38 \pm 92,70$ \\
5. & V & $206,25 \pm 61,24$ & $177,00 \pm 20,80$ & $191,63 \pm 41,02$ \\
6. & VI & $201,50 \pm 56,65$ & $151,25 \pm 38,10$ & $\mathbf{1 7 6 , 2 8} \pm \mathbf{4 7 , 3 8}$ \\
\hline
\end{tabular}

\section{Analisa Statistik}

Berdasarkan hasil uji One-Way Anova didapatkan $\mathrm{p}=0,001$, artinya jika $\mathrm{p}<0,05$ paling tidak terdapat perbedaan kadar glukosa darah yang bermakna pada dua kelompok. Selanjutnya, dilakukan uji Post Hoc dengan metode Bonferroni untuk melihat perbedaan penurunan kadar glukosa darah pada tiap kelompok, jika didapatkan $\mathrm{p}>0,05$ artinya tidak terdapat perbedaan bermakna pada kelompok yang dibandingkan. Pada kelompok bahan uji yaitu IV, V dan kelompok VI dibandingkan dengan kelompok kontrol positif (Glibenklamid) didapatkan bahwa tidak ada perbedaan bermakna dalam menurunkan kadar glukosa darah tikus yang diinduksi aloksan $(\mathrm{p}>0,05)$. Tidak ada perbedaan bermakna juga ditunjukkan kelompok V dan VI terhadap kelompok I (normal). Sedangkan kelompok V dan IV menunjukkan perbedaan efek yang sangat signifikan terhadap penurunan kadar glukosa darah tikus bila dibandingkan dengan kontrol negatif $(p<0,05)$. Kelompok VI (kombinasi) juga menunjukkan tidak ada perbedaan bermakna dengan kelompok IV dan $\mathrm{V}$ (ekstrak tunggal).

Dari data hasil penelitian dapat diketahui bahwa ekstrak kulit buah manggis dan ekstrak daun salam serta kombinasi kedua ekstrak dapat menurunkan kadar glukosa darah. Data hasil 
fitokimia menunjukkan bahwa kedua ekstrak mengandung senyawa metabolit sekunder yaitu Flavonoid dan Saponin. Mekanisme penurunan glukosa darah oleh flavonoid diantaranya dengan mencegah kerusakan sel beta pankreas karena memiliki aktivitas antioksidan dengan cara menenangkan atau menetralkan radikal bebas terkait dengan gugus $\mathrm{OH}$ fenolik sehingga kerusakan sel beta pankreas akibat stres oksidatif dari senyawa radikal (aloksan) akan menurun. Sel-sel beta pankreas akan mengalami regenerasi sehingga dapat memproduksi insulin dan dapat menurunkan kadar glukosa darah. Sedangkan senyawa saponin dapat meningkatkan sensitivitas insulin, menghambat glukoneogenesis dan meningkatkan ekspresi Glucose Transporter 4 (GLUT-4) (Lavle et al, 2016).

Kombinasi ekstrak kulit buah manggis dan ekstrak daun salam dengan dosis masing-masing ekstrak setengah dari dosis ekstrak tunggal memiliki kemampuan menurunkan kadar glukosa darah yang lebih baik dibanding masing-masing ekstrak tunggal, penggunaan kombinasi kedua ekstrak ini dapat memberikan keuntungan yaitu penurunan potensi efek samping dengan efikasi yang lebih baik dibanding penggunaan tunggal masing-masing ekstrak, sehingga pada penelitian ini dilakukan formulasi kombinasi sediaan serbuk dari ekstrak kering kulit buah manggis dan ekstrak kering daun salam.

\section{Sediaan serbuk}

Pada penelitian, setelah masing-masing ekstrak kering dievaluasi, dilakukan formulasi kombinasi ekstrak kering dengan pencampuran semua bahan formula kemudian selanjutnya dievaluasi karakteristik serbuk yang dihasilkan. Setiap sachet berisikan 5 gram terdiri dari bahan aktif (ekstrak) dan bahan eksipien. Tiap formula mengandung ekstrak kering kulit buah manggis 200 mg dan ekstrak kering daun salam $200 \mathrm{mg}$. Bahan eksipien yang digunakan adalah bahan pengikat (PVP K-30), bahan pemanis (Sukralosa) dan bahan pengisi (Laktosa). dari hasil pengamatan organoleptik, sediaan serbuk memiliki memiliki sifat organoleptik yang sama, kecuali pada formula III yaitu pada parameter warna, hal ini dikarenakan adanya perbedaan konsentrasi PVP. Berdasarkan hasil evaluasi waktu alir sediaan serbuk ketiga formula diperoleh rentang hasil waktu alir antara 2,9980 g/detik - 4,8280 g/detik yang menunjukkan bahwa ketiga formula serbuk memenuhi syarat dengan kecepatan alir $<10$ g/detik. Kadar air yang diperoleh antara 7,34\%-8,93\% yang menunjukkan bahwa ketiga formula serbuk memenuhi syarat kadar air yaitu kurang dari 10\% (PerKa BPOM, 2014).

\section{Kesimpulan}

Kulit buah manggis dan daun salam mempunyai efek menurunkan kadar glukosa darah secara bermakna pada tikus dengan kondisi diabetes mellitus yang diinduksi aloksan $125 \mathrm{mg} / \mathrm{kg}$. Ratarata kadar glukosa darah tikus pada kelompok pemberian ekstrak kulit buah manggis sebesar 252,38 mg/dL, ekstrak daun salam 191,63 mg/dL dan kombinasi keduanya 176,28 mg/dL, tidak ada perbedaan bermakna dibandingkan Glibenklamid.

Kombinasi ekstrak kulit buah manggis dan ekstrak daun salam dengan bahan pengikat PVP konsentrasi $3 \%, 4 \%$ dan 5\%, serta pemanis Sukralosa dan bahan pengisi Laktosa mampu menghasilkan sediaan serbuk dengan uji fisik (organoleptik, kadar air dan waktu alir) sesuai dengan yang dipersyaratkan.

\section{Daftar Pustaka}

America Diabetes Association. (2014). Diagnosis and Classification of Diabetes Mellitus, Diabetes Care volume 37, Supplement 1. USA America. (pp 581).

Dewi IL, Sutrisna EM, Azizah T. (2013). Uji Aktivitas Antidiabetes Ekstrak Etanol Daun Salam terhadap Tikus Galur Wistar yang Diinduksi Aloksan. Surakarta: FF Universitas Muhammadiyah Surakarta. (pp 12).

International Diabetes Federation. (2017). IDF Diabetes Atlas Eighth Edition 2017, $8^{\text {th }}$ Edition. (pp 43-46).

Lavle NS, Panchal A. (2016). Role of Flavonoids and Saponins in The Treatment of Diabetes Mellitus. Journal of Pharmaceutical Science and Bioscientific Research. (pp 535-541).

Manurung S, Barung E, Bodhi W. (2012). Efek Antihiperglikemia dari Ekstrak Kulit Buah Manggis (Garcinia mangostana L.) Terhadap Tikus Putih Jantan Galur Wistar (Rattus norvegicus L.) yang Diinduksi Sukrosa. Manado: FMIPA UNSTRAT. (pp 1-10).

Nandhagopal K. Antidiabetic Activity of Karchure Chooranam on Alloxan Induced Diabetic Rats. ISSN: International Journal of Pharma and Bio Sciences. 2013; h 434-439.

Pasaribu F, Sitorus P. (2012). Uji Ekstrak Etanol Kulit Buah Manggis (Garcinia mangostana L.) terhadap Penurunan Kadar Glukosa Darah. USU: Journal of Pharmaceutics and Pharmacology. (pp 1-6).

Peraturan Kepala BPOM Nomor 12 Tahun 2014. (2014). Persyaratan Mutu Obat Tradisional. Jakarta. (pp 11-24).

Pusat Data dan Informasi Kementerian Kesehatan RI. Riset Kesehatan Dasar. Jakarta: Kementerian Kesehatan RI. 2013; h1-6.

Rohyani IS. (2015). Kandungan Fitokimia Beberapa Jenis Tumbuhan Lokal yang sering dimanfaatkan sebagai Bahan Baku Obat di Pulau Lombok. (pp 388-391). 
World Health Organization. (2013). WHO

Traditional Medicine Strategy. (pp 15-16). 